\title{
タイルの接着強度に及ぼすシーラーの安定性に関する研究 STUDY OF THE RELATIONSHIP BETWEEN THE ADHESIVE STRENGTH
OF EXTERIOR WALL TILES AND THE STABILITY
OF POLYMER FILMS USED AS SEALERS
}

\author{
安. 伸二*, 小林一輔** \\ Shinji YASU and Kazusuke KOBAYASHI
}

\begin{abstract}
The relationship between the adhesive strength of exterior wall tiles and the stability of polymer films in alkali environment used as sealers is studied. Concrete specimens with differing alkali contents were prepared, and exterior wall tiles were bonded to these concrete specimens employing various polymer dispersion sealers by the floating method. The tiled specimens were then subjected to outdoor exposure and to alkali immersion tests over three year periods. The results of adhesion tests conducted during exposure are compared to the results of the stability in alkali environment of polymer films. It is pointed out that the adhesion of exterior wall tiles when polymers having ester linkage are used as sealers depends on the stability of the polymer films in alkali environment. Moreover, it is verified that the thicknesses of sealers set out in current building specifications are proper. And it became possible to obtain an index for the selection of suitable polymer dispersions used as sealers for concrete.
\end{abstract}

Keywords : tile,adhesive strength,floating method,polymer dispersion,polymer film,sealer,alkali

タイル, 接着強度, 圧着工法, ポリマーディスパージョン, ポリマーフィルム, シーラー、アルカリ

1.はじめに

近年、外壁タイルをコンクリートに張付ける際に、張 付けモルタルの施工に先だってポリマーディスパージョ ンを塗布する工法が普及している。これは、モルタル中 の水分がコンクリート躯体に吸収されることを防止する 目的で、ポリマーディスパージョンによりポリマーフィ ルムを形成させるもので、コンクリート躯体とモルタル との接着性を高める効果も期待している。この目的に用 いられるポリマーディスパージョンはシーラー（吸水調 整材）と呼ばれており、また、張付けモルタルとしては 一般にシーラーと同じポリマーディスパージョンを用い たポリマーセメントモルタルが用いられている。しかし、 最近の外壁タイルの落下事故の調査結果は、外壁タイル の落下原因がシーラーによって形成されたポリマーフィ ルムのアルカリ少化に関係があることを示唆している”。

シーラーとして用いられるポリマーディスパージョン は一般にエステル結合を有するものが多く、これらは基
本的にはアルカリ溶液によってけん化作用を受けること になる。一方、シーラーによって形成されたポリマーフ イルムはコンクリート躯体に接しているので、滈濃度の アルカリ溶液である紐孔溶液の影響を受けることになり、 接着耐久性の低下が予想される。本文では、この点につ いて明らかにするために、モデル供試体を作製してシー ラーによって形成されたポリマーフィルムの化学的安定 性と压着工法によって作製したタイル供試体の接着強度 との関係について検討を行ったものである。

\section{2. 既往の研究}

\section{1 既往の研究と本研究の関係}

本研究が主に追求したポリマーフィルムの化学的安定 性とタイルの接着強度の関係を明らかにした研究はほと んど見あたらないが、シーラーとして使用したポリマー ディスパージョンの種類とモルタルの接着強度の関係に
*大成建設侏技術研究所 博士(工学)

** 千葉工業大学土木工学科 教授・I博
Technical Research Center, Taisei Corporation, Dr. Eng. Professor of Civil Engineering, Chiba Institute of Technology, Dr. Eng. 
ついては、近藤、篠崎、Sanjayらによる報告がある。

近藤 ${ }^{2)}$ は、エチレン酢酸ビニル系及びポリアクリル酸 エステル系のシーラーを塗布し、室内に 1 年放置した場 合と屋外に 3 年暴露した場合のモルタルの接着強度を調 ベ、以下のような結果を得ている。

1)室内に 1 年故置した供試体の接着強度は、シーラー塗布 の場合の方が無塗布の場合よりも大きく、シーラーとし ては、エチレン・酶酸ビニル系のほうがポリアクリル酸エ ステル系よりも、また1回塗布の場合よりも2回滁布の場 合の方が、それぞれ高い接着強度を示した。

2)屋外に3年間暴露した供試体ではポリアクリル酸エステ ル系のシーラーを用いた場合の接着強度が顕著に低下し た。

篠崎 ${ }^{3)}$ は、エチレン・酢酸ビニル系のシーラーを下地 コンクリートに塗布した場合、ただ単に下地コンクリー 卜の水湿しを行った場合について6年間の屋外暴露の後、 モルタルの接着強度試験を行い、1)水湿しを行った供試 体は、暴露28日で全面剥離を生じたこと、2)シーラーの 3倍液を塗布した供試体は、暴露6年においても接着強度 の低下が認められなかったこと、などを明らかにしてい る。篠崎 ${ }^{4}$ はさらに、同様な供試体について耐水及び㓦 アルカリ加水分解性試験を56日間実施し、酢酸ビニルが 多いシーラーを除き、モルタルの接着強度の低下が生じ なかったことを確認している。

Sanjays) は下地モルタルにエチレン・酢酸ビニル系、ポ リアクリル酸エステル系、スチレン・ブタジエンゴム系 のシーラーを望布した供試体を56日間水浸漬を行った後 にモルタルの接着強度試験を実施し、ポリアクリル酸エ ステル系とスチレン・ブタジエンゴム系のシーラーの塗 布は無塗布の場合よりも接着強度が低下することを明ら かにしている。

2.2 シーラーの機能に関する既往の知見と本研究の関係

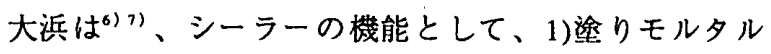
の下地コンクリートへの吸水を抑制してドライアウトの 防止を図るとともに下地からの気泡の発生を防止する、 2)下地コンクリート表層部へのポリマーディスパージョ ンの浸透により被着面の強化を図る、3)接着界面により 形成されるポリマーフィルムを通して化学結合等を形成 する、4)ポリマーフィルムにより接着界面に生じる応力 の緩和を図る、の4点を挙げている。4)の機能について は、大沢8)、小笠原")がコンクリートにシーラーを塗布 後モルタルを接着した試験体にせん断力を加え、シーラ 一がコンクリートの变形に対する緩衝効果があることを 実験で確認している。

一方、難波 ${ }^{10)}$ は、結合材がいずれもセメント系材料 である下地コンクリートとポリマーセメントモルタルは セメントの水和によって良くなじむので、この面からは 両者が直接接することが望ましい。このような観点から、
ドライアウトを防止するためにシーラーを用いて両者の 界面に形成させるポリマーフィルムは不連続なものでな ければならない、と述べている。この場合、不連続の程 度は、ドライアウトが防止できる範囲で不連続性が高い ことが望ましいことになる。標集塗布量はこのような不 連続膜を形成するのに必要な量として定められたものと 考える。ドライアウトを防止する必要がある期間はモル タルを施工ししてら長くとも2週間程度であり、この時 点でシーラーによって形成されたポリマーフィルムの役 割は終ったことになる。従って、タイルの接着強度は、 下地コンクリートとモルタルというセメント硬化体どう しの接着強度と雨者の界面に存在するポリマーフィルム と両者の接着強度（上記の大浜による3)の機能による） が相互に関与する複雑な接着機構によって支配されるこ とになる。タイルの接着強度に及ほす前者と後者の奇与 率は、ポリマーフィルムの不連続の程度とこれを形成さ せるために用いたポリマーディスパージョンの化学的安 定性によって支配され、しかもこれらは時間の経過とと もに変化するはずである。

ポリマーデイスパージョンの化学的安定性に関しては、 下地コンクリート中の細孔溶液のアルカリ濃度とポリマ ーティスパージョンの種類によって影響される。また、 ポリマーフィルムの不連続の程度は下地コンクリートの 表面状態に大きい変化がなければ主にシーラーの塗厚に よって左右される。近年、現場では標準塗布量の何倍も のシーラーを叙有するような厚塗が行われる傾问がある ことが指摘されているが、このような厚塗は連続膜を形 成させることになり、この場合、タイルの接着強度は結 局のところ、ポリマーディスパージョンの化学的安定性 によって支配されることになる。このようなケースに関 して近藤は、エチレン・酢酸ビニル系とポリアクリル酸 エステル系のポリマーディスパージョンをシーラーとし て用いた場合について3年間の屋外暴露実験を行い、シ ーラーが造膜している（連続膜を形成している）場合に は、シーラーの化学的少化により剥離を起こす可能性が あると指摘している。

本研究は、压着工法によって施工されたタイルの接着 強度とシーラーによって形成されたポリマーフィルムの 高アルカリ環境下における化学的安定性との関係を明ら かにすることにより、シーラーに適したポリマーディス パージョンとその望ましい塗布量についての知見を得る ことを目的として実施したものである。

\section{3. 実験方法}

\section{1 実験の手法}

本研究では、压着工法によって施工されるタイルの接 着強度とシーラーによって形成されたポリマーフィルム 
の化学的安定性との関係を明らかにするために、以下の ような2つのシリーズの実験を行った。

シリーズI：下地コンクリートに標集量のシーラーを 望布した場合について、接着蚛度の経時 変化に及ほすポリマーデスパージョン の種類と下地コンクリートのアルカリ濃 度の影響を調べる実験

シリーズI：下地コンクリートに塗布するシーラーの 染布量を標準量の3倍量及び5倍量とした 場合について、接着強度の経時変化に及 ほす塗布量の影響を調べる実験

さて、压着工法によって施工されたタイルの接着強度 は、シーラーの塗布を通じて形成されるポリマーフィル ムの化学的安定性のみによって支配されるのではなく、 温度変化及び湿度変化に起因するdifferential movement (thermal movement と moistutre movement) などの物理 的要因によっても左右されることは良く知られている。 本研究では、このような物理的要因による影䇺を分離し て調べるため、接着強度を調べる供試体を屋外に暴露す ると同時に室内においてアルカリ溶液中に漫犢する場合 についても実験を行った。後者の環境では上記のような 物理的要因の影響をほとんど受けないので、これら2つ の環境において得られた結果を対比することによって、 接着強度の経時変化に及ほす物理的要因の影響を評価で きると考えたからである。

\section{2 実験の概要}

シーラーとして用いたポリマーディスパージョンは、 シリーズIの実験の場合には、エチレン・酢酸ビニル共 重合体系（以下、EVAと略称）、メタクリル酸メチル. アクリル酸ブチル共重合体系（以下、PAE-1と略称）、 アクリル酸ブチル・スチレン共重合体系（以下、PAE-2と 略称）及びポリ酰酸ビニル系（以下、PVACと略称）・の4 種類、シリーズ【の実験ではEVA、PAE-1の2種類である。 これらのポリマーディスパージョンの性質を表-1に示す。

表-i. ポリマーディスパージョンの性質

\begin{tabular}{|c|c|c|c|c|c|}
\hline $\begin{array}{c}\text { シーラー } \\
\text { の種類 }\end{array}$ & $\begin{array}{c}\text { 固形分 } \\
(\%)\end{array}$ & $\begin{array}{c}\mathrm{pH} \\
\left(20^{\circ} \mathrm{C}\right)\end{array}$ & $\begin{array}{c}\text { 粘度 } \\
\left(20^{\circ} \mathrm{C} \mathrm{cP}\right)\end{array}$ & $\begin{array}{c}\text { 比重 } \\
\left(20^{\circ} \mathrm{C}\right)\end{array}$ & $\begin{array}{c}\text { 最低造膜 } \\
\text { 温度 }\left({ }^{\circ} \mathrm{C}\right)\end{array}$ \\
\hline EVA & 45.1 & 6.0 & 640 & 1.06 & 0 \\
\hline PAE-1 & 45.5 & 8.8 & 110 & 1.06 & 10 \\
\hline PAE-2 & 34.8 & 7.6 & 170 & 1.03 & 0 \\
\hline PVAC & 45.7 & 5.8 & 1300 & 1.08 & 2 \\
\hline
\end{tabular}

下地コンクリートは、そのアルカリ量を変化させるた めに、シリーズ I では2Nの水酸化ナトリウム溶液を練り 混ぜ水に添加することにより、使用したセメント中の等 価捘算 $\mathrm{Na} 2 \mathrm{O}$ 量 $(\mathrm{R} 2 \mathrm{O})$ がそれぞれ0.58\%（無添加）、1.2\%、
1.8\%、シリーズ円では1.8\%になるようにした。

暴露期間は、シリーズ I の場合には1080日とし、シ门. 一ズ円の場合には540日とした。

供試体は、下地コンクリートにシーラーを叙布してポ リマーフィルムを形成させた後、ポリマ一セメントモル タルを介してタイルを接着して作製した。供試体の形状 寸法は、シリーズIの実験の場合には、300×300×100 $\mathrm{mm}$ (下地コンクリート） の平板状、シリーズ円の奏験で は、 $100 \times 100 \times 400 \mathrm{~mm}$ (下地コンクリート) の梁状のも のである。これらの上にシーラーを介して施工された約 $5 \mathrm{~mm}$ 厚さのポリマーセメントモルタル層と同時に圧着さ れたタイルが存在する。

3.3 使用材料

セメントは普通ポルトランドセメントを用いた。

下地コンクリートに用いた骨材は、細骨材が荒川産川 砂 $(5 \mathrm{~mm}$ 以下)、粗骨材が秩父两神産砕石 ( $20 \mathrm{~mm}$ 以下)であ る。張付けモルタルには、5号及び6号珪砂をを用いた。

タイルは、JIS A 5209 (缸磁器質タイル) に規定する 磁器質タイルの45二丁掛（色：乳白色、寸法：95×45m、 厚さ：7.3mm、裹足高さ：1.5m) を用いた。

3.4 コンクリート及びポリマーセメントモルタルの調合

(1) コンクリートの調合

タイルの張付けに用いたコンクリートの調合は表-2に 示すように、水セメント比 $60 \%$ 、スランプを $12 \mathrm{~cm}$ で一定 にした。

表-2 コンクリートの調合

\begin{tabular}{|c|c|c|c|c|c|c|c|}
\hline \multirow{2}{*}{$\begin{array}{c}\text { 粗骨材 } \\
\text { の最大 } \\
\text { 寸法 } \\
(\mathrm{mm})\end{array}$} & \multirow{2}{*}{$\begin{array}{l}\text { 目標 } \\
\text { スラ } \\
シ フ ゚ ~ \\
\text { シ } \mathrm{cm})\end{array}$} & \multirow{2}{*}{$\begin{array}{c}\text { 水セメ } \\
\text { ント比 } \\
(\%)\end{array}$} & \multirow{2}{*}{$\begin{array}{c}\text { 細骨 } \\
\text { 材率 } \\
(\%)\end{array}$} & \multicolumn{4}{|c|}{ 单位量 $\left(\mathrm{kg} / \mathrm{m}^{3}\right)$} \\
\hline & & & & $\begin{array}{l}\text { セx } \\
\text { ント }\end{array}$ & 水 & 紐骨材 & 粗骨材 \\
\hline 20 & 12 & 60 & 48 & 342 & 205 & 856 & 960 \\
\hline
\end{tabular}

（2）ポリマーセメントモルタルの調合

ポリマーセメントモルタルの調合は、外装タイルの張 付けモルタルの仕様に準じて重量比でセメント：砂（絶 乾状態の5号珪砂と6号球砂を同量混合したもの）：水の 重量比が $1: 1: 0.34$ で、ポリマーセメント比 $=10 \%$ 、メチ ルセルロースをセメント重量の $0.2 \%$ とした。

3.5 供試体の作製

（1）下地コンクリートの作製

下地コンクリートは、脱型後 $20^{\circ} \mathrm{C} 、 70 \% \mathrm{RH}$ の恒温室 において28日間養生した。

（2）供試体の作製

下地コンクリートは養生後、打込み面のレイタンスを ワイヤーブラシで完全に除去後、シーラー塗布を行った。 塗布は、原液：水 $=1 ： 2$ の3倍希釈液（固形分約 $15 \%$ ）。 に より行った。雓布量は、標準量の場合は固形分が $30 \mathrm{~g} / \mathrm{m}^{2}$ 
になるようにした。標準量の3倍量と5倍量塗布する供試 体は、固形分がそれぞれ $90 \mathrm{~g} / \mathrm{m}^{2} 、 150 \mathrm{~g} / \mathrm{m}^{2}$ になるようにし た。シーラーを塗布した試験体は、20\%、70\%RHの恒 温室に1日間養生した。

タイルは、JIS R 5201 (セメントの物理試験方法)に 準じた方法で練り混ぜたポリマーセメントモルタルを約 $5 \mathrm{~mm}$ 塗った下地コンクリートの上に置き、圧着工法で張 付けた。ポリマーセメントモルタルを練り混ぜた後夕イ ルを張付けるまでの時間は5分以内とした。タイルを張 付けた供試体は、2日間 $20^{\circ} \mathrm{C} 、 70 \% \mathrm{RH}$ の恒温室に2日間 養生した後、暴露試験を行った。

3.6 供試体の暴露方法

（1）屋外暴露

暴露方法は、供試体をJIS A 1410 (プラスチック建築 材料の屋外暴露試験方法）に準じて水平面から30度傾け、 方角は1日中太陽光に暴露されるように南向きに設置し た。設置場所は、習志野市の障害物のない日当りの良い 建物の屋上である。

（2）アルカリ水漫漬

実際の建物では、シーラーにより形成されたポリマー フィルム面に建物躯体のコンクリートの毛細管空隙を通 してアルカリ分を弇んだ水が供給される。アルカリ水浸 漬は、この条件をモデル化するために行ったものである。 なお、コンクリートの細孔溶液のアルカリは、 $\mathrm{Na}^{+} 、 \mathrm{~K}^{+}$ が主であり、Ca年微量であること、 $\mathrm{pH}$ が13程度である ことを考慮して、アルカリ水として0.1Nの水酸化ナトリ ウム溶液を用いた。

供試体は、図-1に示すようにタイル面を空気中に曝し、 下部から上部にアルカリ水が移動するように側面をエポ キシ樹脂でシールした。アルカリの浸漬高さは、コンク リート面までとし、常時この面まで浸潰するようにアル カリ液の供給を行った。

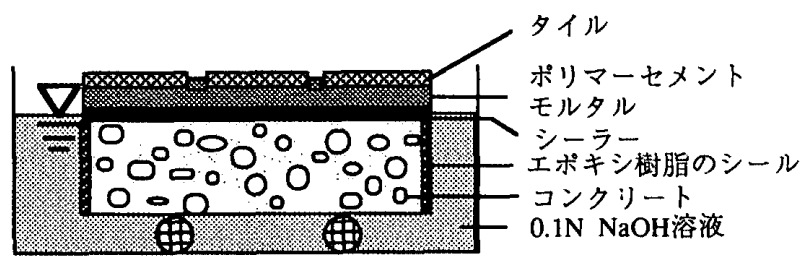

図-1 アルカリ水漫㣴試験体の設置方法

\section{7 試験方法}

(1) 接着強度試験

タイルの接着強度試験の供試体は、試験を行うタイル の周囲の目地にコンクリートに達するまで切込みを入れ て周囲との縁を切った後、タイルに鋼製アタッチメント をエポキシ樹脂接着剤を用いて張付けた。

接着強度試験は建研式接着試験機と容量30トンのリー レ型油压式引張試験機を用いて行った。後者は図-2に示
すように、4個の小型油圧シリンダーによって試験体を 支持する試作装置を試験機のクロスヘッド上部に装着し、 試験体をその上に乗せて偏心荷重を除いた状態で引張試 験を行うものである。当初は前者の試験機を用いて接着 試験を行っていたが、偏心荷重などの点で信頼性に疑問 を抱いたため、途中から後者を使用したが、同一の試験 体に張り付けられたタイルについて両者の試験機を用い て接着試験を行った結果では、いずれの試験機を用いて も大きな差は認められなかった。なお、それぞれシリー ズIの実験では暴露日数1080日後、シリーズII の実験で は筷露日数540日後で後者の試験機を用いて接着強度試 験を実施した。

接着強度は、タイルの接着破壊までに要した引張荷重 を接着面皘で除し、3個の平均値として求めた。破断箇 所の割合は、破壊面をトレース用紙に写し取った後、切 り取って重量測定を行い調べた。
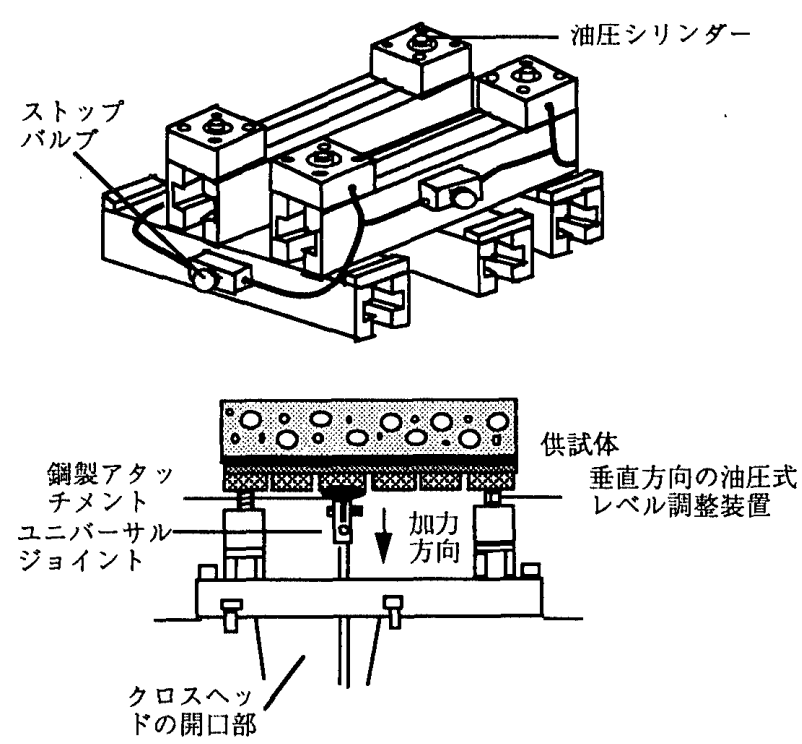

図-2＼cjkstart試作装置と万能試験機への設置状況

（2）赤外分光分析

接着強度試験の結果とシーラーの劣化の関連性を検討 するために行ったもので、試料は標準量の5倍量を塗布 したシーラーから採取した。試料は、接着強度試験で剥 がしたタイル試験片の唇付けモルタルの表面を3N塩酸に 1時間浸漬、十分に水洗した後ピンセットで採取した。 採取した試料は、純水で洗浄、真空乾燥を行った後に分 析に供した。

赤外分光分析は、試料に砂が固着していたので、フッ 化水素酸溶液に漫漬して砂を溶解した後、 $\mathrm{KBr}$ 錠剂法に より 400〜 4000 $\mathrm{cm}^{-1}$ の波数範罒で行った。

なお、あらかじめシーラー状に調製したポリマーフィ ルムを塩酸とフッ酸に浸漬し、それらの薬品が亦外分光

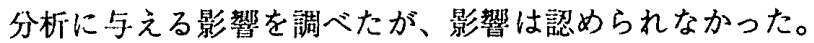




\section{4. シリーズIの実験結果と考察}

図-3〜6は、それぞれEVA系、2種類のPAE系及びPVAC 系のシーラーをアルカリ量の異なるコンクリート表面に 標準量塗布して作製した供試体を、それぞれ屋外暴露及 び実験室のアルカリ溶液に浸漬した場合における接着強 度の経時変化を示したものである。図-7に試料の破壊状 況を示すが、その破壊は一部を除き、主にコンクリート とモルタルの界面であうた。

これらの図のうち、PVAC系の一部の結果を除き、共 通的に認められる傾向は、暴露期間の経過とともに接着 強度は次第に上昇するが、暴露期間が500～700日に達す ると低下し始めることである。

一般に压着工法によって施工されるタイルの接着強度 は、大別して温度変化や湿度変化に起因する物理的な要 因とシーラーのアルカリ劣化のような化学的要因の2つ の要因によって支配されると言われている。しかし、今 回のように屋外暴露を行った場合の接着強度の経時変化 が、室内におけるアルカリ溶液浸漬の場合と同様な傾向 を示したことは、これらのシーラーを使用した場合の夕 イルの接着耐久性が、シーラーのアルカリ劣化という化 学的要因によって支配されることを意味する。これらの シーラーはエステル結合を有しているが、このエステル 結合がアルカリ環境下においてはけん化反応によって切 断される結果、劣化が進行するのである。この切断が急
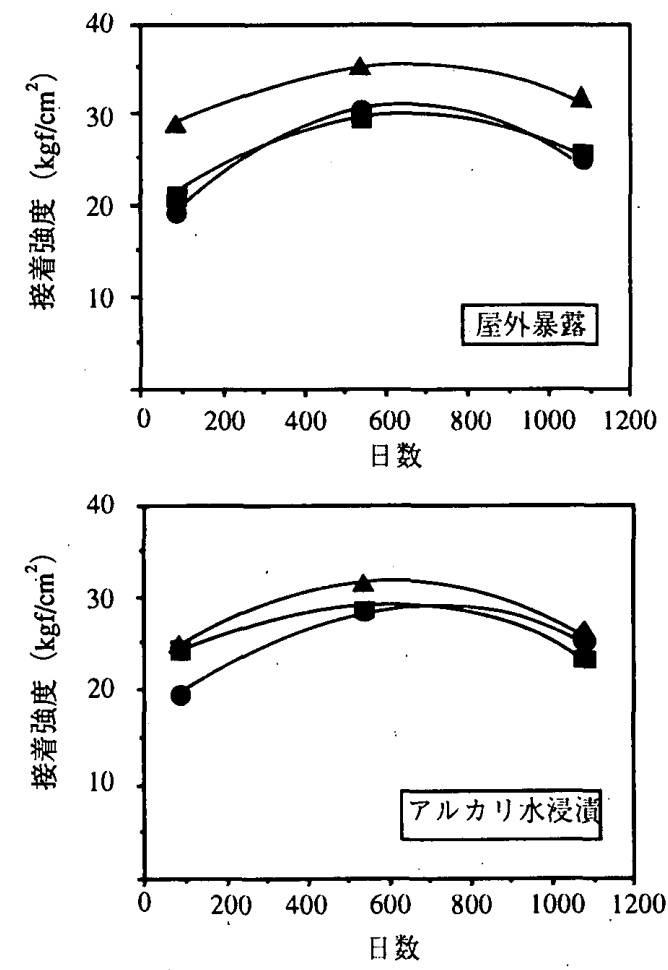

$<$ 凡例 $>$ $\mathrm{R} 2 \mathrm{O}=0.58 \%$

$\Delta: \mathrm{R} 2 \mathrm{O}=1.2 \%$

$: \mathrm{R} 2 \mathrm{O}=1.8 \%$

図-3 EVAを標準量塗布した供試体の接着強度变化
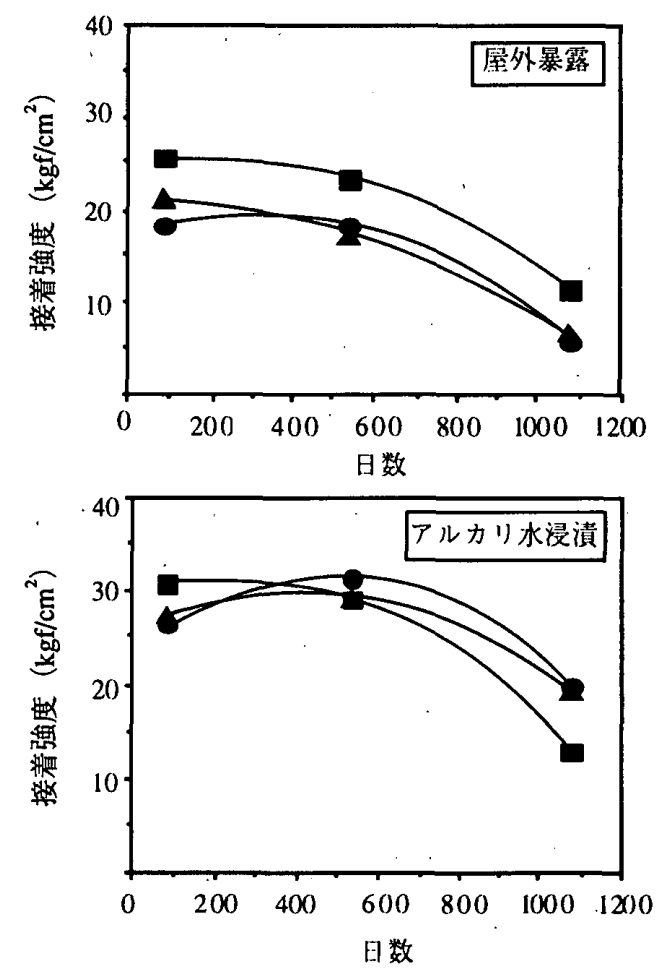

$<凡$ 例 $>$

$: \mathrm{R} 2 \mathrm{O}=0.58 \% \quad \Delta \quad: \mathrm{R} 2 \mathrm{O}=1.2 \%$ $: \mathrm{R} 2 \mathrm{O}=1.8 \%$

図-4 PAE-1を標準量叙布した供試体の接着強度変化
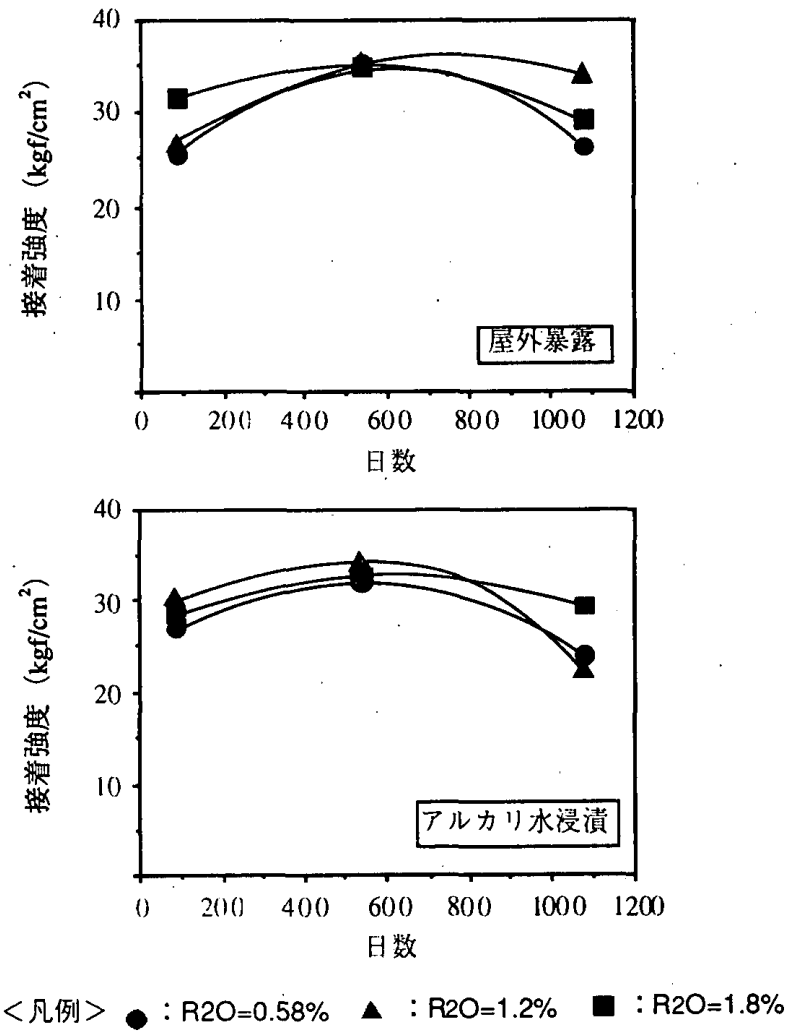

図-5 PAE-2を標潗提涂乕した供試体の接普強度变化 

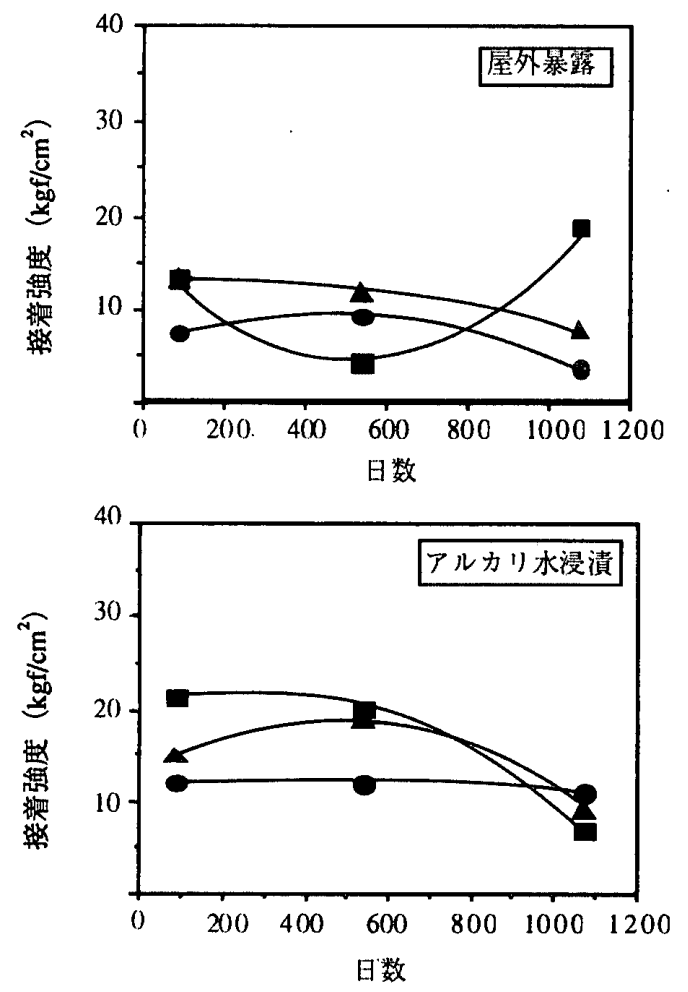

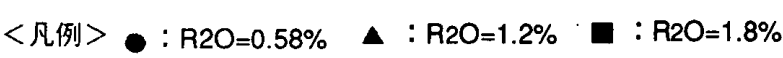

図-6 PVACを標準量塗布した供試体の接着強度変化

速に進行する時期は接着強度が低下し始める時期（500 ～700日）とほほ対応していることが確認されている ${ }^{22}$ 。

さて、図-3〜5に示したようなシーラーを標準量塗布 した場合における接着強度の経時変化に関しては、図-8 に示したような機構が考えられる。即ち、暴露初期にお いては、タイルの接着強度は主にシーラーとセメント硬 化体との接着機構に依存し、この場合、接着強度は初期 にはシーラーによって形成されたポリマーフィルムの下 地コンクリートに対する粘着力によって左右されるが、 時間の経過とともにアルカリに対する反応性の影響を受 けるようになる。後者の要因に関しては、ある段階まで は接着力を増大させるが、けん化反応によるポりマーフ イルムの劣化が進行するに従って接着力は次第に低下す る。一方、ポリマーフィルムが不連続の部分では、ポリ マーセメントモルタルと下地コンクリートの結合がセメ ントの水和反応によって進行する。

写真-1はEVA系のシーラーを標準量叙布して形成され たモルタル表面のSEM像を示したものである。部分的に ポリマーフィルム (黒色部分)の間にセメント水和物 (白 色部分) が認められ、シーラーを標準量塗布した場合に はポリマーフィルムが存在しない部分が局所的に存在す ることが分かる。

タイルの接着強度は以上のような買なる接着機構によ

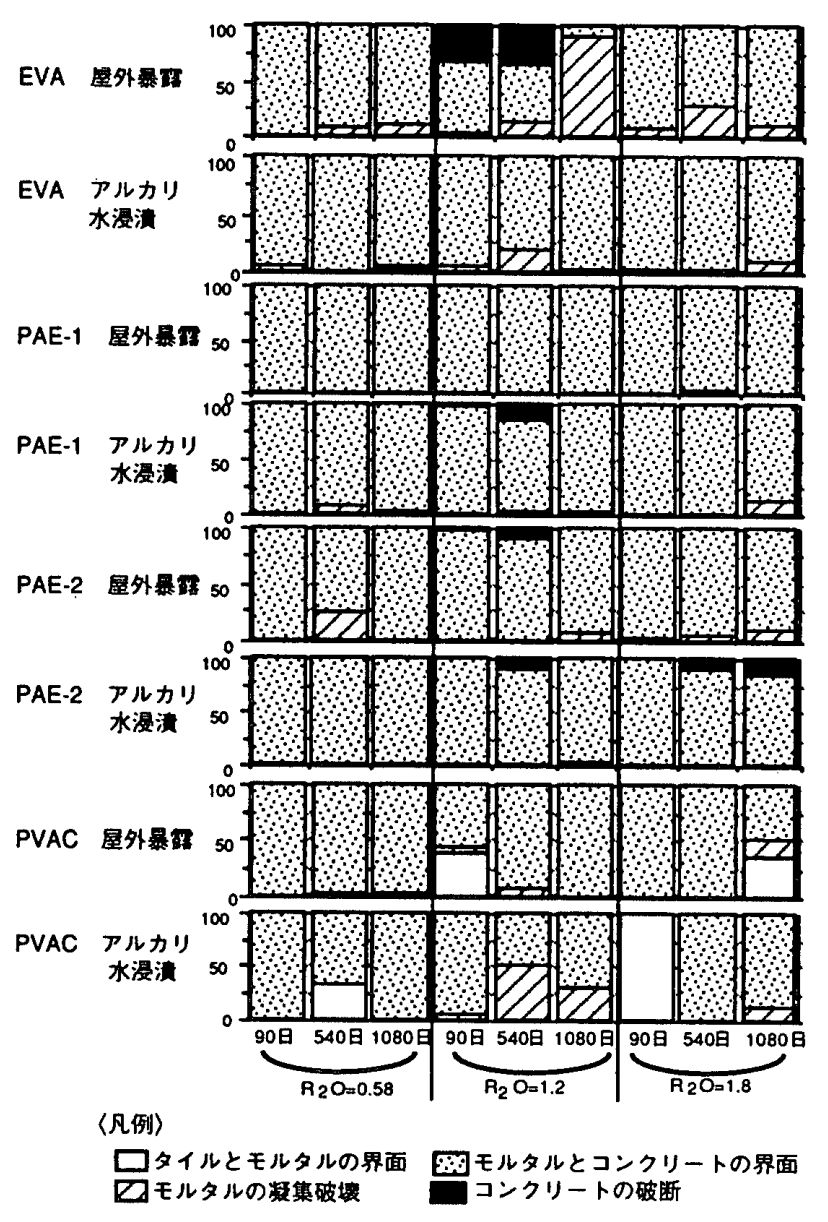

図-7 シリーズ I 供試体の破断状況

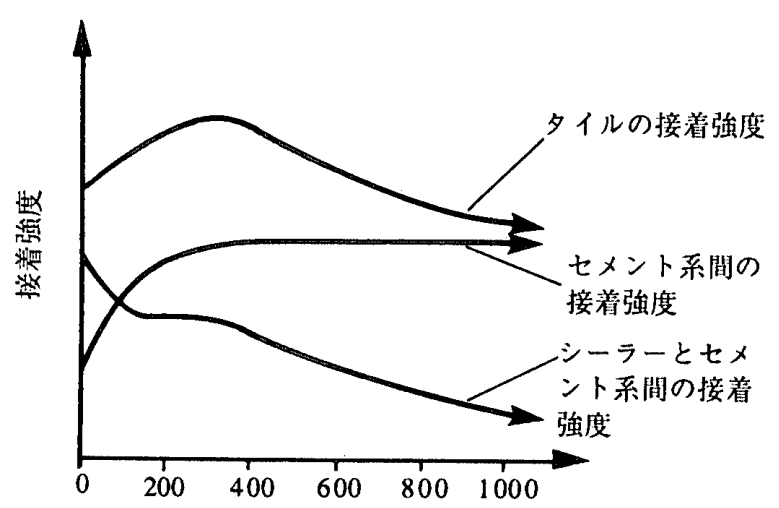

図-8 シーラーを染布したタイルの接着強度変化の モデル図

って得られる接着力の和として表される。セメント系相 互閐の結合によって生じる接着力は大体において材齢3 ヶ月程度で最大値に達するので、その後の接着力はポリ マーフィルムのアルカリに対する挙動によって支配され ることになる。例えば、アルカリとの反応速度による接 着力の変化、反応が進行してフィルムが溶解した場合に 


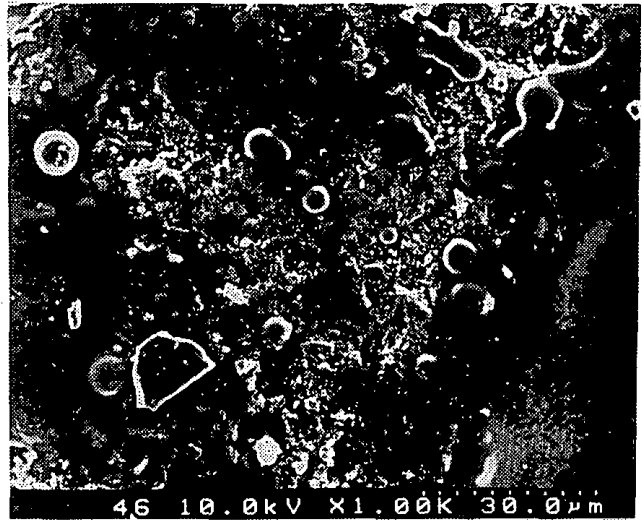

写真-1 EVAシーラーを標準量塗布したモルタル表面

生じる溶解残さの行方などによって左右されることにな る。

PVAC系の場合には、EVA系やPAE系のものに比べて やや異なる傾向が認められる。即ち、屋外羕露の場合、 接着強度はアルカリ量が $0.58 \%$ と $1.2 \%$ の場合には暴露期 間が長期にわたるに従うて低下する傾向が認められるが、 アルカリ量が1.8\%の場合には暴露期閒が500日前後まで は比較的急速に低市した接着強度が、その後は増大に転 し、、3年を経過すると初期の接着強度を上回る值を示し ている。

図-9は、このような特異な接着強度の経時変化を説明 するためのモデルである。まず、PVAC系のポリマーフ イルムの特徵としてアルカリ溶液に接すると容易に溶解 する ${ }^{12)}$ 。暴露初期にはシーラーとして形成されたポリマ ーフィルムは下地コンクリートから供給されるアルカリ

（細孔溶液）の作用を受けて溶解が進行するが、その速 度は細孔溶液のアルカリ濃度が高いほど顕著に現われる。 また、溶解の進行に伴ってポリマーフィルムの凝集力が 低下するため接着強度も低下する（分解期）。

下地コンクリートのアルカリ濃度が著しく高い場合、

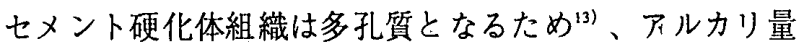
が1.8\%の場合には細孔溶液の移動も活発になる。このよ うな供試体を屋外に暴露した場合、乾燥湿潤の繰返しゃ 温度変化により溶解成分は少しずつ下地コンクリート中 の空隙などに吸収され、最終的には界面にはほとんどシ ーラーが存在しないと同様な状態になる。即ち、同じセ メント系である下地コンクリートとポリマーセメントモ ルタルが直接接することになるので、未水和セメント粒 子の水和反応の進行により全体としての接着力が上帠す ることになる。一方、アルカリ溶液に漫涉した場合には 屋外暴露に比べて物質移動が生じにくいので溶解成分が 界面に残存する結果、接着強度は低下の一途を辿ること になる。

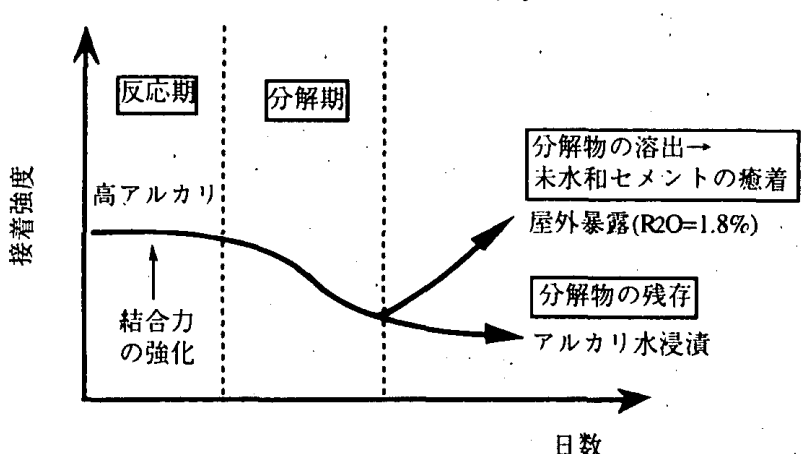

図-9 PVACシーラーのアルカリの作用と接着強度変化 のモデル図

\section{5. シリーズПの実験結果と考察}

図-10〜11はそれぞれEVA系及びPAE系のシーラーを下 地コンクリート（ $\left.\mathrm{R}_{2} \mathrm{O}=1.8 \%\right)$ にそれぞれ標集量、3倍量、 5倍量叙布して作製した供試体を：屋外暴露及び垁験室 内でアルカリ溶液に浸潰した場合における接着強度の経 時変化を示したものである。図-12に試料の破壊状況を 示すが、一部を除き、その破壊はコンクリートとモル夕 ルの界面、即ち、シーラーの部分で生じていた。これら の図に共通して認められる傾向は、1)シーラーの塗布量 の多い供試体の接着強度は暴露期間が 1 年を越える時点
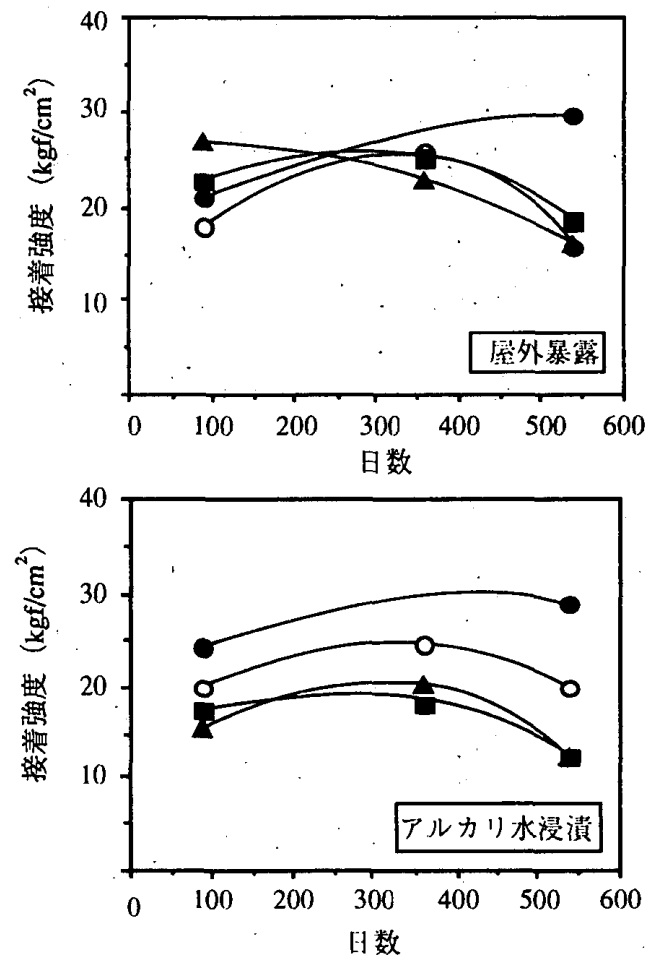

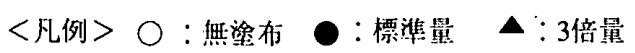
:5倍蹱

図-10 EVAの塗布舅を変えた供試体の接着強度変化 

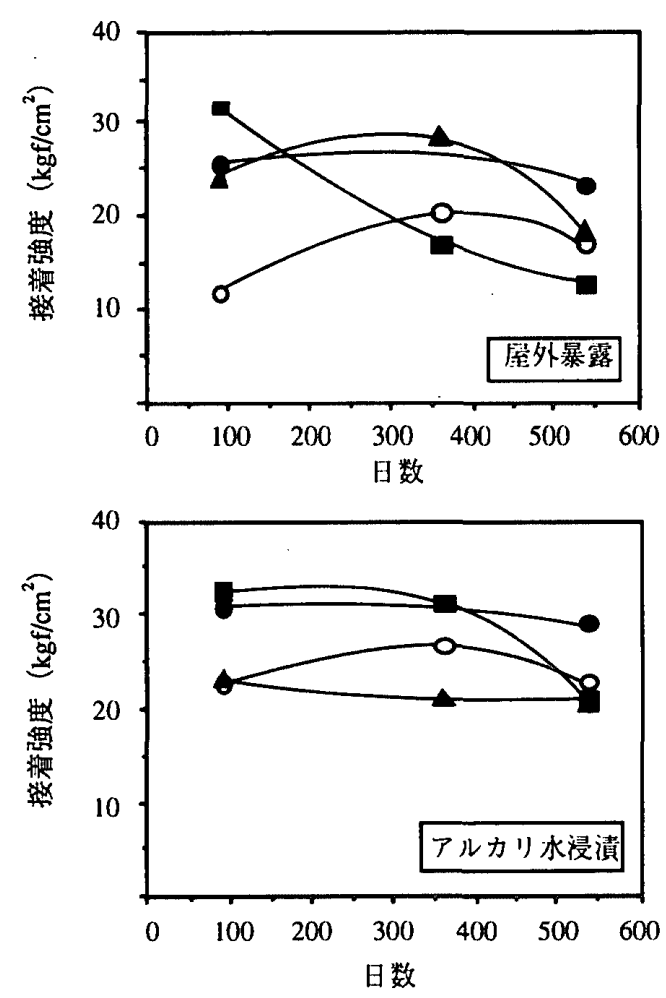

$<凡$ 例 $>O:$ 與塗布

: 標準量

A : 3倍量

: 5 倍吕

図-11 PAE-1の塗布量を変えた供試体の接着強度変化

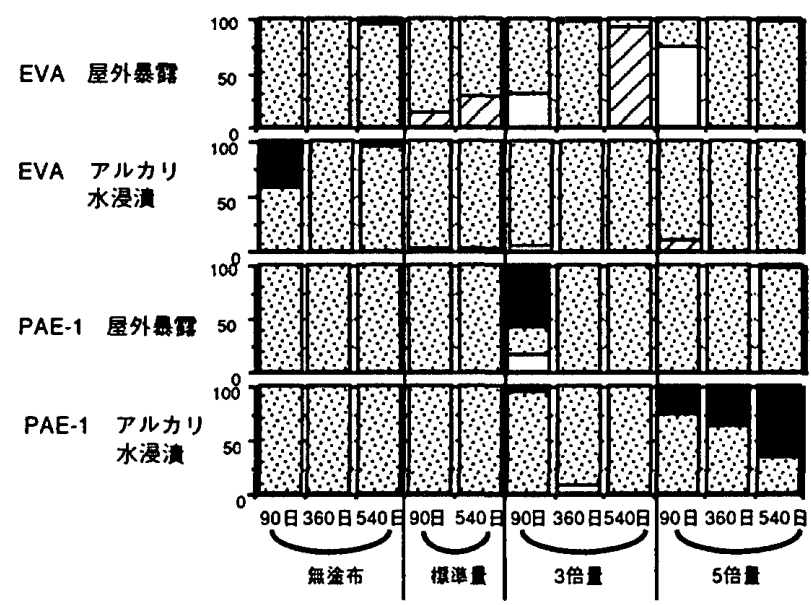

〈凡例〉

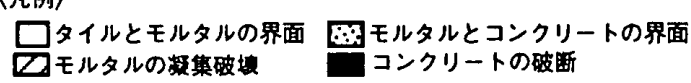

図-12シリーズI供試体の破断状況

から顕著に低下し始めるが、シーラーを標準量塗布した 供試体では暴露 1 年6ケ月の時点でも強庤の変化は少ない こと、2)このような接着強度の低下傾向は暴露条件の如 何を問わず認められること、の2点である。

下地コンクリートに対して多量のシーラーを塗布した 場合に、接着強度の低下が顕著となる理由は、既に述べ たように形成されたポリマーフィルムが連続膜となった
ためと考えられる。写真-2は、このことを確かめるため に水セメント比が $65 \%$ 3倍量整布して形成されたポリマーフィルムの表面状態 を走査型電子顕微鏡によって観察したSEM像を示したも のである。この写真から、ポリマーフィルムは連続膜状 態となっていることが示されており、このことは夕イル の接着強度がシーラーとして使用したポリマーディスパ ージョンの化学的安定性によって支配されることを意味 する。即ち、下地コンクリートに供給される高濃度のア ルカリ $\left(\mathrm{R}_{2} \mathrm{O}=1.8 \%\right)$ 溶液の作用によるポリマーフィル 么の劣化が接着強度の低下を招く原因と考えられる。

図-13は、EVA系のようなエステル結合を有するポリ マーの少化が、けん化反応によって進行することを確認 するために、暴露日数が540日の時点でEVA系の供試体 (図-10に示したシーラーの㳊布量を標準量の5倍量とし たもの）から採取したポリマーフィルムについて赤外分 光分析を行った絬果である。図-13から、屋外暴露とア ルカリ水浸淦の場合の赤外吸収スペクトルを塗布前の場

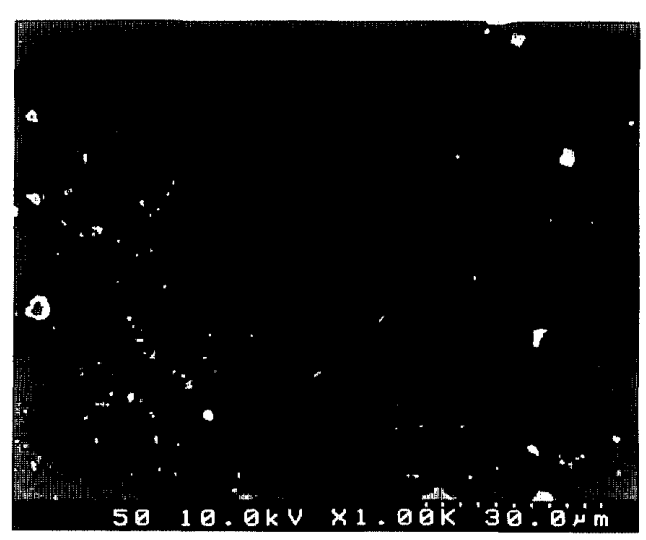

写真-2 EVAシーラーを3倍量染布したモルタル表面

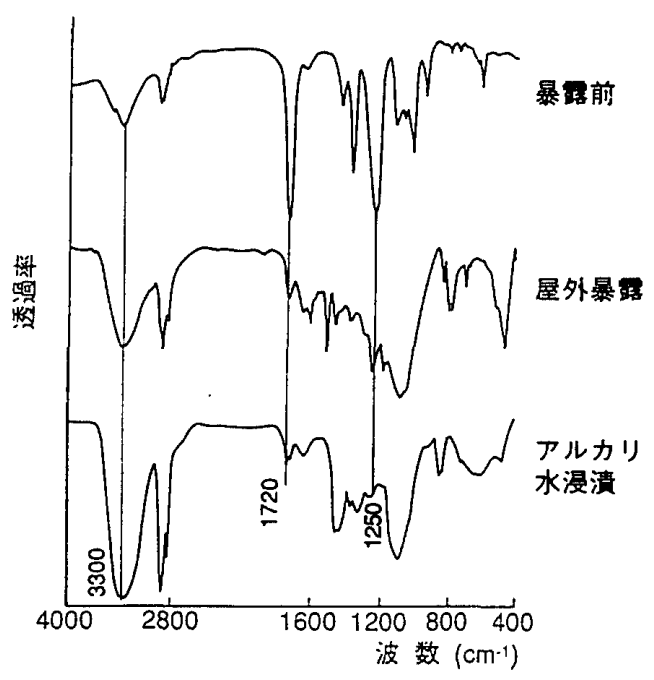

図-13 EVA供試体のシーラーの赤外分光分析結果 
合と比較すると、1)エステル結合の存在を示す $1720 \mathrm{~cm}^{-1}$ と $1250 \mathrm{~cm}^{-1}$ のピークが小さくなっており、この傾向は特 にアルカリ水漫漬の場合に顕著であること、2) OH:の存 在を示す $3300 \mathrm{~cm}^{-1}$ のピークが塗布前の場合より大きくな っていること、などがわかる。1)の結果は、高濃度のア ルカリによってエステル結合が切断されたことを示して おり、2)の結果は、式-1に示すようにエチレン・酢酸ビニ ル共重合体がエチレンビニールアルコールに変化したこ とを示している。以上の結果は、EVA系のようなエステ ル結合を有するシーラーによって形成されたポリマーフ イルムが高濃度のアルカリの作用によってエステル側鎖 が切断され、劣化が進行することを裏づけている。

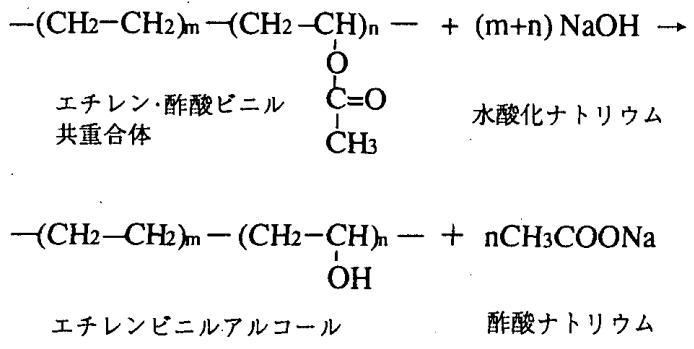

\section{6 結論}

压着工法によって施工されたタイルの接着耐久性に及 ほすすーラーの化学的安定性について検討を行った結果、 以下のような結論が得られた。

（1）ポリアクリル酸エステル系及びエチレン・酢酸ビ二 ル共重合体系のようなエステル結合を有するシーラーを 用いて施工したタイルの接着耐久性を支配する主な要因 は、下地コンクリートから供給されるアルカリ溶液によ るシーラーの劣化であることが明らかとなった。

(2) ポリマーディスパージョンの種類と接着耐久性の 関係は、アクリル酸ブチル・スチレン系やエチレン・酢酸 ビニル系のような共重合体系のシーラーを用いた場合に ポリ酢酸ビニル単独重合体より優れた接着耐久性が得ら れることが確かめられた。

なお、エチレン・酢酸ビニル系のシーラーを用いた場 合でも、これを厚塗りした場合には、シーラーのアルカ リ劣化によりタイルの接着強度が低下することが確かめ られた。

（3）圧着工法によってタイルを施工する場合に現在適 用されているシーラーの標準叙布量は、下地コンクリー トとポリマーセメントモルタルの界面に不連続なポリマ ーフィルムを形成させることによってドライアウトの防 止というシーラー本来の機能と、そのアルカリ少化とい う異なる要因を考虑した合理的なものであり、この塗布 量の時に最も優れた接着耐久性が得られることが確認さ れた。
しかし、以上の結果はあくまでも3 年間という限定さ れた暴露試験を通じて得られたものであり、より長期間 における接着酎久性を予測するための基礎資料を与えた ものである。長期間における夕イルの接着耐久性を定量 的に予測するためには今後さらなる検討が必要と考える。

シーラーの使用にあたっては、その本来の目的である 張付け材料であるモルタルのドライアウトを防止した後 は、コンクリートとモルタル間の接着強度に影厩を与え ない形で存在することが望ましい。

\section{あとがき}

本論文は、著者の 1 人が千葉工業大学大学院在学中に 博士論文 ${ }^{14)}$ として取りまとめた内容の一部である。

\section{[謝辞 ]}

本研究の奏施に当たって多大な御協力を頂いた千葉工 業大学の小原二郎理事、千葉工業大学土木工学科の森弥 広講師及びコンクリート研究室の卒研生に対して深甚な る感謝の意を表します。

\section{参考文献}

1）上村克郎：外壁住上げの剥落とその対策、第3会全国外壁補修工事業共同 組合連合会金沢総会における諘演要旨、1991.5.28

2）近藤照夫他：セメントモルタル叙り用吸水調整材の性能評価、日本建築 学会大会学術講演梗概集、（その1）：1990年10月、pp.123〜124、(その 2）:1991年9月、pp.35〜36、（その3）:1991年9月、pp.37〜38、（その 4) : 1993年9月、pp.929 930

3）䇥崎征夫他：合成エマルションシーラを用いた外壁モルタル淮りエ法に

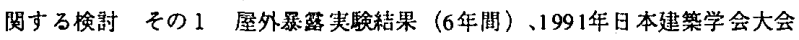
学術梗概集、pp. $41 \sim 42$

4）䇫崎征夫他：モルタル接濐における躯体面処理材としての焦布形エマル ションに関する検討、昭和60年日本建築学会大会学術梗概集、pp.583 584 5) Sanjay N.PAREEK、大浜器彦、出村克宣：ADHESION DURABIUTY OF BONDED.MORTAR TO POLYMER DISPERSION COATED MORTAR SUBUSTOR ATES、1991年 日本建築学会大会学術梗概集、pp. 39 40

6）大捠諪彦：ボリマーラテックス及びエマルションの建設材料としての利 用、Polyfile（ボリファイル）、pp.39〜44、1989年11月

7) Sanjay N.PAREEK、大捠茄㢁、出村克宣：ボリマーディスバージョンを 用いた下地処理による鉒継ぎモルタルの接着性改善効果、1989年 日本建築 学会大会学術梗概集、pp. 27 30

8）大沢清八：左官用モルタルの付着性能の評価に関する研究、日本建築学 会粗造系論文報告集、第441号、pp.,17 24、1992年11月

9）小笠原和博、平居孝之他：モルタル叙り用吸水調整材に関する研究 吸 水調整材望布界面の挙動について、日本建築仕上学会 1992 年大会講演会研究 発表論文集、Pp. 27 30

10）難波连太郎：タイル落下事故のいろいろ 原因と対策、建䓩保全、 Vol.67、pp.89 102、1990年9月

11）難波莲太郎：コンクリート構造物の外壁におけるタイル・モルタル仕上 層の剥離防此対策、コンクリート工学、Vol.29、No.9、pp.5 18、1991.9 12）安伸…、小林一輔：ポリマーディスバージョンによって形成されたボ リフィルムの耐アルカリ性に関する2、3の考察、コンクリート工学論文集、 Vol.5、No.1、 pp. $99 \sim 108 、 1994$

13）小林一輔、小酉盛衛：セメント中のアルカリがコンクリートの諸性状に 及は古影裂、東京大学生産技術研究所報告、第35巻、第2 号、pp.53、平成元 年3月

14）安 伸二：ポリマーティスパージョンによって形成されたポリマーフィ ルムとそのコンクリート睘境下に拐り安定性に関する研究、平成 5 年度子 葉工業大学博士課程諭文

（1994年 8 月 24 日原稿受理，1995年 5 月 16 日採用決定） 